\title{
Colonial control or terroir tourism? The case of Houghton's White Burgundy
}

\section{Tara Brabazon}

Charles Sturt University, Australia

Is Burgundy more than a region in France, or could it refer to a style of wine making? Food and wine are not only derived from a place. They make a place. Other industries are enabled through food and wine, particularly tourism. 'Region' has a distinctive role in framing the brand and profile of a wine bottle. 'Region' mitigates risk for a consumer. Region is a proxy for quality. This article investigates the impact of the legal protection and control of regionality on formerly colonized nations, with particular consequences on wine industries. By exploring Houghton's White Burgundy and its transformation into White Classic, the impact of protecting regionality on formerly colonized nations is revealed.

\section{Key Words: Colonial control, terroir tourism, White Burgundy, Swan Valley.}

Article Info: Received: September 26, 2014; Revised: November 21, 2014; Accepted: November 25, 2014; Online: November 30, 2014.

\section{Introduction}

To insist on regional difference and the preservation of cultural identity is not backward or reactionary. It is in fact the latest thing, an outcome possible only because of recent changes that have yet to be fully consolidated.

Jean-Louis Flandrin and Massimo Montanari (1996, 552)

Global. Local. Between these two words resides an array of mitigating terms to manage space, culture, people, history, capital and policy. These words include glocal, trans-local, national and regional. The latter term activates the complexity of regionalism and regionality. This paper takes the spaces around regionality as its focus, with particular attention on a bottle of wine from a minor winery. Working with and through Houghton's White Burgundy, which became White Classic in 2004 in response to European laws and treaties, I investigate the impact of

\section{Correspondence address}

Address: School of Teacher Education at Charles Sturt University, Panorama Avenue Bathurst NSW 2795, Australia.

Phone: (02)63384248 | Email: tbrabazon@csu.edu.au 
European determinations of 'region' on a formerly colonized nation. This is not a paper offering a general analysis of 'new world' wines from South Africa, New Zealand or Chile. This is not a paper providing an investigation of Australian wines in general. Instead a minor wine, as part of a minor label, from a minor wine region, is tracked, revealing the often undocumented impact of European determinations of'region.'

After the credit crunch and crash, the conventional truths, maxims and assumptions about economic development, social justice, consumerism, citizenship, industrialization, post-industrialization and the 'new economy' were in flux. Regional development is a necessity but also clichéd. E. Warwick Murray and John Overton recognized the importance of "place-making strategies" (2011, 419). They argued that, "A wine's geographical provenance is important as a selling point and something that can differentiate one wine from another in a market characterised by many thousands of brands" (2011,419). While capital and corporations move with ease over national borders, a fetishization of very specific geography is a form of resistance. ${ }^{1}$ Yet the function of regionalism is much more complex. The global wine industry - with mobile capital, consumers, marketing and wine makers - commodifies regionalism. Therefore, regionalism is not a reaction to globalization, but enables it. This regionalism manifests differently in the 'Old' and 'New' world. Such a division is - in itself - colonial. Indigenous Australians are - debatably - the oldest culture in the world. Yet within a colonial discourse, Europe is the centre of culture and tradition.

While there are challenges in managing the conflictual ideologies of region and regionality, David Balaam and Michael Carey's corrective is important: "the regional approach collapses previously separate categories of political and economic issues into a more useful category of the political economy of agriculture in various regions" $(1981,1)$. Regionalism is not only a way to reconfigure economic policy, but also a strategy to develop the interdependence of cities, towns, rural environments and trans-local movements. This paper moves through four parts. Firstly, I investigate theories of region and then move into determinations of appellation. The third section introduces the Swan Valley and the paper concludes with a focus on Houghton's White Burgundy/White Classic.

Globalization was based on the industrial revolution, ${ }^{2}$ which was founded on the

\footnotetext{
${ }^{1}$ Alexander Nutzenadel and Frank Trentmann stated that, "The trade in new foods went hand in hand with processes of imperial expansion and migration, new systems of production, distribution and consumption, tensions between cultural imperialism, on the one hand, and hybridization and resistance on the other, the rise of new organized producer and consumer agencies, battles between free trade and protectionism, emerging new knowledge regimes in nutrition and science, and a reshaping of social and ethnic identities," from Nutzenadel and Trentmann, (2008, 5-6).

${ }^{2}$ Industrialization and food production occupy an ambivalent place in food students, particularly when inflected by the slow food movement. Rachel Lauden offered a fascinating correct to the celebration of the local, deindustrialized 'natural food. She argued that, "In the nick of time, in the 1880s, the industrialization of food got under way long after the production of other common items of consumption such as textiles and clothing had been mechanized," p. 41. She also warned of the dangers in celebrating a 'traditional' past that did not exist: "If we romanticize the past, we may miss the fact that it is the modern, global, industrial economy (not the local resources of the wintry country around New York, Boston, or Chicago) that allows us to savor traditional, peasant, fresh and natural foods. Virgin olive oil, Thai fish sauce, and Udon noodles come to us thanks to international marketing. Fresh and natural loom so large because we can take for granted the preserved and processed staples - salt, flour, sugar, chocolate, oils, coffee, tea - produced by agribusiness and food corporations," p. 42-43, from Lauden (2001, 36-44).
} 
agrarian revolution (Miller and Deutsch, 2009: 42-43). Population shifted from rural to urban environments. Rurality became a space of deficit, lack and absence (Reid, Green, Cooper, Hastings, Lock and White, 2010). Rurality is an ideology, and adds a complexity to the understanding of regionality. Donehower, Hogg and Schell's definition moved beyond population size and towards the mode of interaction.

We define 'rural' as a quantitative measure, involving statistics on population and region as described by the U.S. Census; as a geographic term denoting particular regions and areas or spaces and places; and as a cultural term, one that involves the interaction of people in groups and communities (2007).

Therefore, demography, geography and culture align to frame, define, label and configure. Such a definition provides the mechanism to understand not only the plurality of rural environments, but also how to reshape the meanings of this space. John Overton and Jo Heitger argued,

Rural places acquire value in different ways and geographers have adopted a range of approaches to understand the way value is created in land and place ... Rural land is valued in diverse ways. Embedded in land are values that different people ascribe to it in different ways at different times. Such values may be economic, cultural, social or spiritual and may be held by individuals or collectively $(2008,440)$.

The key challenge since the industrial revolution - which has shaped rurality - is that more food needed to be produced by fewer people. Therefore food was integral to industrialization and colonization, and central to globalization. Taste, like culture, is highly ideological (Carolan, 2011). The regions that gain profile and branding $^{3}$ are empowered, often in Europe and protected through the legal and economic power of the European Union. This is local knowledge for global consumption. However, conflictual geographies emerge (Figure 1).

This is a product available from an Australian supermarket: Woolworths. It is their 'gold' range, and therefore the logo - the large W - disconnects this supposedly authentic and elite product from industrial food consumption. The layering of geographies is complex. Woolworths is an Australian supermarket. 'English' describes the former colonizer of Australia. Shropshire is an historic rural county in the midlands of England. However the small stamp to the left of the packaging refers to 'Artisan English cheese' that is 'traditionally made in Leicestershire.' Upon turning the product packaging over, the geographical confusion increases. While the product was "Made in England," it was "Packed for Woolworths Ltd. 1 Woolworths Way Bella Vista NSW." However a New Zealand Address is also featured - 80 Favona Road, Mangere, Auckland, New Zealand - and a New Zealand-based website: www.progressive.co.nz. This website runs Countdown supermarkets in New Zealand, part of Woolworths. The assumption therefore is that this item is also distributed in Countdowns, which also explains the ' $W$ ' rather than the full 'Woolworths' on the packaging. So what is 'authentic' and 'artisanal' about this Shropshire cheese made in Leicestershire?

\footnotetext{
${ }^{3}$ Branding is not a negative force. Within a creative industries discourse, it provides the foundation for economic development, often in post-and de-industrialized cities. Such a branding can also facilitate environmental protection, sustainability, the conservation of heritage seeds and rural social justice.
} 


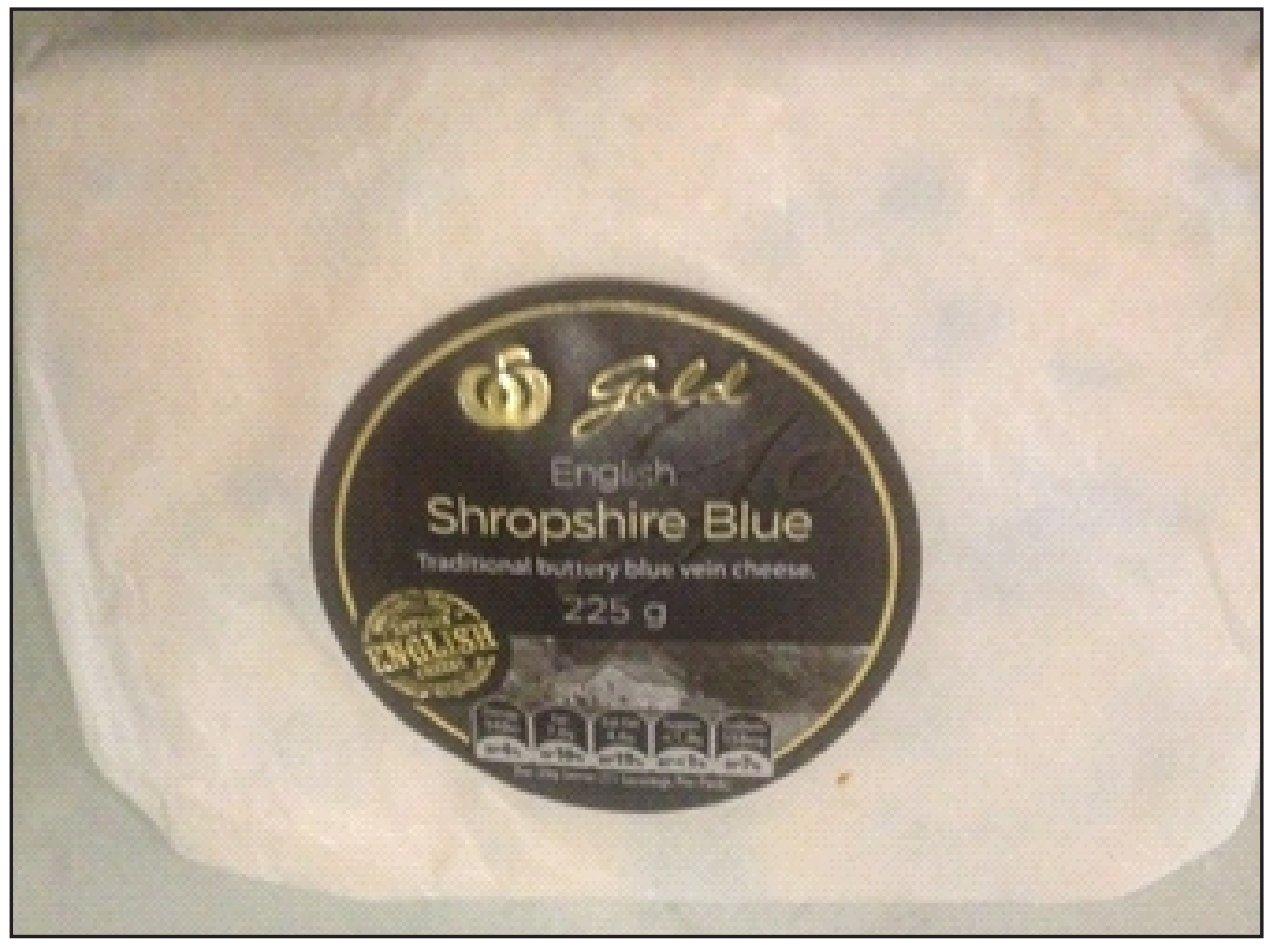

Figure 1. Shropshire Blue (Photograph by Tara Brabazon)

The justification (perhaps) of this oddity is carried in and through the French notion of terroir. Overton described this term as, "a broad concept encompassing the physical characteristics of the land (its soil, climate, topography) and its human dimensions (culture, history, technology)" (2010, 753). Such a concept is not only 'about' physical characteristics. It captures a distinctiveness of place and culture that marinates, inhabits and enlivens wine, cheese, coffee, olives or lavender. It is "the consumption of a particular construction of that place" (Overton, 2010, 761). Euroterroirs link food with a region, requiring a legacy of 75 years, a body of knowledge and current practice (Mason, 1999, 11-20). As shown later in this paper, such assumptions are forgetful of colonization.

Beyond terroir, an array of alternative food movements exist in response to globalization, including the slow food movement, farmers' markets, communitysupported agriculture organizations, organic food movement, environmentalism, the macrobiotic movement and vegan and vegetarian communities (Belasco, 1989). Such strategies construct different supply chains between producers and consumers. Because regionalism - as a term - floats around and between the local and the global, it can be used by both globalizing forces and those movements resisting it. It can be protectionist. Regionalism - in its European manifestation is responding to the success of the 'new world' (formerly colonized nations) in creating competitive foodstuffs for the European market. Whenever celebrating the regional - burgundy (or Burgundy) and champagne (or Champagne) - there is an assumption that these regions produce authentic goods. There is confusion between the origin and the authentic. Different places reveal an array of distinctions in history, language, type of product grown, production methods and 
specificities of landscape like rivers, lakes and proximity to the sea or mountains. A range of legal structures protect the links between place and product.

This labelling of authentic regional food can expand inequalities as the 'quality produce' increases in price. A convincing argument about 'the regional' and placebased descriptions for food comes from Laura DeLind. She asks for an understanding of local food beyond "the reductionist rationality of the marketplace" (2006, 126). DeLind values soil and biodiversity, building new models for understanding the relationship between place, food and bodies $(2006,137)$. She does not value or validate the legal controls on food, but ask that consumers are 'embodied' and situate their life and choices into space and place.

Enabling people to become better consumers or producers of local food, then, is not enough. Of themselves, such roles are too mechanical, too, superficial, and the relationships they describe too insular. We need to move beyond political and environmental correctness (i.e., eating locally because it is important, progressive, and trendy). Our challenge, as academics and practitioners, as people engaged in relocating the food system, will be to find ways to stretch our experiences and sensibilities to a point where 'the local' as food, as farmland, as the culture and ecology of real places starts to 'be' us and define us wherever we are ... we will be engaging in a place-based identity politics that has the potential to keep us grounded, affirmed, and diverse (2006, 142-143).

Food is not only derived from a place. It makes a place. Other industries are enabled, particularly tourism (Boniface, 2003). So while tourism is economically important, it also holds an andragogical function, teaching consumers about the place in which food is grown and made (Hall, Sharples, Cambourne, Macionis, 2002). This is why 'region' has a particular role on a wine bottle. It mitigates risk for a consumer. Placing all this information in printed form accompanying, or on the label of, a bottle of wine is an impossible task. Region is a proxy for quality.

\section{The appellation}

The forming of the five senses is a labour of the entire history of the world down to the present. Karl Marx (2011)

The senses have a history and a sociology. If there is an Empire of the Senses (Howes, 2005), then visuality is the colonizer, dominating hearing, touch, taste and smell. Through schooling, visual literacy is taught through reading words. Writing is also a form of visual communication. The digital environment has increased the integration of text, images and sound, navigated through a screen and hypertext link. Visual literacies in analogue and digital environments confirm the distinction between seeing and believing. As John Berger's career has shown, seeing is a literacy, a subjective interpretation of the world (1990). In the hierarchy of the senses, taste is ranked below sight and sound in both its capacity to convey information and the literacy to decode signifiers. The visual - the packaging of food, the colour of fresh produce and the appellation mark on some goods - creates a tight link between the senses of sight and taste.

Regionality is not only protected. It is legally enforced through AOC (Appellation d'Origine Controlee). The French wine industry is based on the AOC, linking 
wine production to a specific region. Food is also inserted into this system, with Roquefort cheese and Normandy camembert being examples. The first French Law in this area emerged in 1919: the Law for the Protection of the Place of origin. The European Union's PDO finds its origins in this French AOC system. In 1993, Australia passed legislation to permit registration of "geographical indicators" such as regions. (Australian-European Commission Ministerial Consultations, 1994, 368). The reason for the introduction of this law was so that Australia could fulfill the requirements of the Uruguay Round of trade negotiations with the European Union (Australian-European Commission Ministerial Consultations). From these negotiations in the early 1990s, by the Council Regulation (EC) No 510/2006 from March 2006 (Council Regulation, 2006), the European Union enforced a three tier strategy to create:

- PDO (Protected Designation of Origin): Products are produced and prepared in a geographical area, with unique methods. Examples include Prosciutto di Parma, Calasparra rice and Gorgonzola.

- PGI (Protected Geographic Indication): Products are produced in a geographical area with attributes - or 'qualities' - attained from that area.

-TSG (Traditional Speciality Guaranteed): A product does not gain specificity from an origin, but holds a traditional character. This could refer to a mode or means of production. Examples include Belgium beer or Italian mozzarella (Council Regulation, 2006).

The Australian Agreement recognized "reciprocal protection" (Agreement between Australia and the European Community on Trade in Wine, 1994) of wine names. The names that could not be used in Australia were chianti, madeira, malaga, cava and beaujolais. Some words were given a transitional period to stop their use: burgundy, chablis, champagne, port, sauternes, sherry and claret. This process becomes even stranger when reading Annex II of the 1994 agreement. "Traditional Expressions" (TEs) are also restricted including pale, dry, medium, golden and cream. These words supposedly captured the "protected quality" of the wine. Australia received little from this agreement. Certainly, 103 Australian locations were recognized by virtue of the PGI. These included Northern Territory, South Eastern Australia, Rutherglen, Barossa valley, Margaret River and Mudgee. This agreement exchanged the use of burgundy for mudgee.

What does this mode of legally enforced regionalization represent? It is glib to confirm that it continues European colonization by other means. Such agreements aimed to protect and develop the regionality of food and to affirm 'authenticity' for consumers buying products (Royamo, 2006). The assumption was that nonEuropean goods were not 'authentic' and were 'inferior' to the European goods. To provide one example of the consequences of these agreements and the case study in this assignment, Houghton's White Burgundy, first vintaged in 1937, had to change its name because 'Burgundy' was a PGI. Therefore the product was renamed White Classic. The question remains: is Burgundy more than a region in France, or could it refer to a style of wine making?

From this legal basis, the importance of regional marketing - and marketing of regions - is clear. The legal restrictions on the use of 'champagne' and 'burgundy' have expanded into the food industry, where 'protection' of particular regional 
foods has emerged. Stilton cheese and Cornish pasties are two examples. However such policies and laws must favour older nations and regions. Is Welsh Lamb better than New Zealand lamb? Is there 'something' in the Welsh countryside, grass and air that produces better meat? The longer the history, the more intricate and interesting the story for branding and marketing. This 'protection' of particular places and regions reveals disturbing colonial overtones.

The Commonwealth Trade Marks Act (1995) in Australia confirmed that "a sign recognised in that country as a sign indicating that the goods ... originated in that country, region or locality and ... have a quality, reputation or other characteristic attributable to their geographical origin" (Dechent and Sadler, 2010,3). A place becomes a sign. The question remains: what is the value in this sign? Susanna Dechent and Pauline Sadler capture the consequences and conflict of legally enforceable geographical indicators.

The problem arises when the new wine is not in fact produced in the region after which it is named, because increasingly countries worldwide are recognising that their GIs are something to be jealously guarded. The name is associated by consumers with certain information which may be about quality, flavour or type. This reputation has an economic worth because consumers will choose to purchase one product rather than another on the basis of what they think they know about it $(2010,3)$.

The difficulty emerges when this ideology - this assumption about place and product - is then enforced through a range of legal frameworks, including trademarks, Agricultural Policy (European Commission 2014) and Intellectual Property law (World Intellectual Property Organization 2014). TRIPS (Trade-related aspects of intellectual property rights) (Lindquist, 1998-9) includes Article 22 (1).

Geographical indications are, for the purposes of this Agreement, indications which identify a good as originating in the territory of a Member, or a region or locality in that territory, where a given quality, reputation or other characteristic of the good is essentially attributable to its geographical origin (TRIPS, Article 22).

It also refers to wine specifically in Article 23

Each member shall provide the legal means ... to prevent use of a geographical indication identifying wines for wines not originating in the place indicated by the geographical indication in question ... even when the true origin of the goods is indicated ... or accompanied by expressions such as 'kind,' 'type,' 'style, 'imitation' or the like.

Such articles are beyond a celebration of terroir. They are regulation of a particular way of labelling and structuring the world (Barham, 2003). It is not only an association of place and product, but a statement that a product is of quality because it is from that place.

Colonization is an imposition of language, religion, traditions and history, to the detriment, loss and displacement of indigenous languages, religions, traditions and history. To claim particular words and styles and tether them to a region now, after indigenous practices and behaviours have been marginalized, ignored or ridiculed for two centuries, is cheeky at best and disgraceful at worst. It is both brutal and unnecessary to draw an historical line and state that it was acceptable 
when 'we' introduced a language and behavior in the 19th century as it was in the interests of empire, but now that 'we' no longer hold that power, the former colonized nations must 'invent' their own practices after two hundred years of injustice. Therefore, with protected areas, labels, regions and trademarks in place in the former imperial nations - reinforced by the economic clout of the EU - new economic and cultural strategies must be found in these 'new' nations and regions.

The appellation is an ideological bundle that tethers region, authenticity, origin, difference and quality. It aligns with terroir: the idea that a particular micro-landscape and micro-climate creates distinctiveness in food or wine. This is not an ahistorical connection. Climate change is altering viticulture and the extremes of temperatures in Europe (Jones, White, Cooper, Storchmann, 2013). Burgundy is changing ( $\mathrm{Xu}$, Castel, Richard, Cuccia, Bois). What is being protected is as changeable as the weather. A further agent of transformation is the rise of new wine industries, techniques and wine makers. These new industries have been enabled through the mobility of techniques, money and consultancy from wine makers. Stuart Pigott provided a fascinating commentary on "The truth of Thai wine." He met a winemaker who "has rapidly mastered the peculiarities of viticulture in a climatic zone where the vine is as completely a stranger as I am in this culture" (Pigott, 2006, 76). There is a foundation for this expertise.

As I take my seat on the plane to visit Chateau de Loci, a silver-haired Australian with a musical lilt to his voice introduces himself as Dorham Mann, a wine producer from the Swan Valley in Western Australia who consults for Chateau de Loci. "This is my tenth visit in three years, but I am not the winemaker," he explains. "The lads make the wines. They've very conscientious and hard-working." Given that Dorham's father, Jack Mann, made his name with dry Chenin Blanc - he created Houghton's White Burgundy launched with the 1937 vintage, one of the first modern-style table wines produced in Australia - it is appropriate that he should be advising another producer of wines from this unfashionable grape (Pigott, 2006, 77).

At the legal juncture where specific locations have been fetishized and trademarked, the mobility of knowledge, consultancies and capital is questioning the scale and scope of the distinctiveness of both wine and food. That - to use Stuart Pigott's title - is the truth in Thai wine. This new industry is showing what is possible and how the limitations of weather, climate and soil can be managed with expertise, capital and hard work. The role of the winemaker is critical, determining when to pick the grapes, fermentation, how yeast works with the sugars, the blending and the functionality of French or American oak.

The economic value of these labels is not only in the sale of product but also with the rural tourism emerging from it, including visiting wineries and cheese manufacturers. This is rural tourism. This is terroir tourism (Holland, Smith and Jones, 2014, 275-291). It is also "rural culture economics" (Ray, 1998, 3-20). Vadour was honest in his recognition of "viticultural terroir" (2002, 117-141), realizing that the distinctiveness of grapes emerges through four different areas:

Plant growing

Territory

Identity

Advertising (2002). 
Appellation is an historical geography. The nostalgia that emerges through legally claiming particular names is a denial of modern wine capitalism. Moran for example recognized the role of wine makers - rather than landscape - in creating the distinctiveness of wine (Moran, 2001, 32-51). Winemaking is a job, and wine makers move between companies. Put another way, the key question is, "What makes Napa?" (Hira and Swartz, 2014). Negotiating between local, regional and national allegiances can create "locational advantage" (Hira and Swartz, 2014, 37 53). Appellations secure locational advantage, affirming that a landscape creates unique flavours. But this is a conservative process and agenda. Technological change can make an impact. A recent study showed that for a segment of the population, digitization maintains a role in wine selection (Higgins, McGarry Wolf and Wolf, 2014, 19-27). A study of 'millenials' found that they "rely less on geographic cues such as region of origin to determine wine quality and pay more attention to medals won, label imagery, and alcohol content" (Atkin and Thatch, $2012,54)$. Differentiation is the key marketing strategy. The signifiers of wine often placed on the bottle and reliant on visual literacy - can create a wine information literacy. That is, consumers / decoders can match their requirements of a wine with the information provided to them on the bottle while comparing it with prior experience.

Protecting the appellation is based on assumptions of profound landscape distinctions, rather than the mobile techniques and technologies of agriculture, farmers and producers. Food systems are globalized through digitization, deregulation and the influence of transnational corporations (Lyons, 2006). But if the weather and landscape are a determinant, then the two most extreme weather conditions in which wine grapes are grown - Ontario and the Swan Valley - offer the most claim for an appellation. The Swan Valley is one of the hottest locations where grapes are grown and wine is made in the world. The wineries around Lake Ontario in Canada reach temperatures that enable ice wine. Canada also maintains an appellation system. In 2000, the Vintner's Quality Alliance Ontario claimed particular places as trademarks. Yet is the 'value' in the place or the process of wine making. Put another way; is the branding of Canadian wine best advantaged through the phrase "Niagara Peninsula" or "icewine"? The latter captures the distinctiveness in mode of production.

At its best, terroir captures landscape and climate, but also the human history of work, technology and expertise. A place is being sold. This is more than consumption. It is place marketing (Banks, Kelly, Lewis, Sharpe, 2007). Terroir is a glass into which wine is poured, creating a thinking space for critics, journalists, wine makers and educators (Colman, 2008). These wine places are constructed. They are not 'natural.' Nature is being bent, shaped and digitized to create a sharp and crisp alignment of production and consumption (Overton and Heitger, 2008, 440449). The goal of shaping wine in this way is to develop a series of experiences, a drinking culture (Wilson, 2005).

New Zealand has been slow in determining how wine industry locations in the nation are protected. Considering the dominance of Sauvignon Blanc and Marlborough, New Zealand has moved slowly to configure and enforce Geographical Indicators for its food and wine (Overton, 2010, 754). Part of this process is to invest in and understand rural places (Overton and Heitger, 2008). While 'New World' wines have increased their market share on the 'Old World,' they have often done so by cutting away Old World regulatory mechanisms. 
The focus is on varieties not location. In the case of New Zealand, there may be an option and opportunity to invest in Terroir, but with a digital twist. New Zealand production techniques are expensive: small scale operators produce a variable quantity and quality of wine because of the variations and unpredictability of the climate. The 'ultra-premium' market is targeted (Saunders, 2004, 311). Investing in the distinctiveness of place is a way to justify the high prices for the low yield. The relationship between place and taste is ambiguous, difficult to measure and even more difficult to manage. Terroir is not the start or end of this narrative of regional development. Understandings of the winescape are transforming. At its most basic and binarial, Peter Saunders split the ideological directives of the wine world.

The European Way: Wine of the Land.

The New World Way: Wine of the grape (Saunders, 2004, 5).

Taste is a sense. The expression of that sense follows experience. Narratives, stories, myths and marketing can fill the space between taste and interpretation. With the legal controls on particular terms that link land and wine in Europe, it is not surprising that wine brand and variety of grape now dominate Australia, Chile and South Africa. New Zealand remains an intriguing case because of both Marlborough and Martinborough. Therefore how the wine is organized appellationally, varietally or through proprietary-blending - is visual grammar for prospective consumers.

\section{Swan Valley}

Drinking alcohol is a key practice in the expression of identity.

Drinking is a political act. Thomas Wilson (2004)

For small wine growing regions without an international profile, the challenge is how to gain economic sustainability. The Swan Valley is an urban wine region and much less known than the more southern region of Margaret River. There are few wine regions around the world that are within a thirty minute drive of a CBD. The Barossa Valley is comprised of a series of country towns situated eighty kilometres north-east of Adelaide. The Swan Valley is part of the metropolitan area. What makes this unusual and seemingly attractive geography of urban wine difficult to market is that there are a range of more famous wine making towns and regions in the south west of the state. Margaret River wines are the most famous, but other areas include Pemberton, Denmark, Geographe, Peel, Pemberton, Porongurup and Mt. Barker. To align these towns, a branding strategy and logo was designed and used to unify south-western wine. A brightly coloured logo assumes the appearance of spilled wine in the shape of the continent of Australia, but features a mark over the south west region of W.A. The logo reads "Australia - west - dominion of wine" (Figure 2).

This branding is unusual, but historically and geographically resonant. Distinctiveness matters. Wine is "a saturated market" (Wagner, Olsen and Thach, 2007). Certainly this region is part of a nation known for winemaking. 


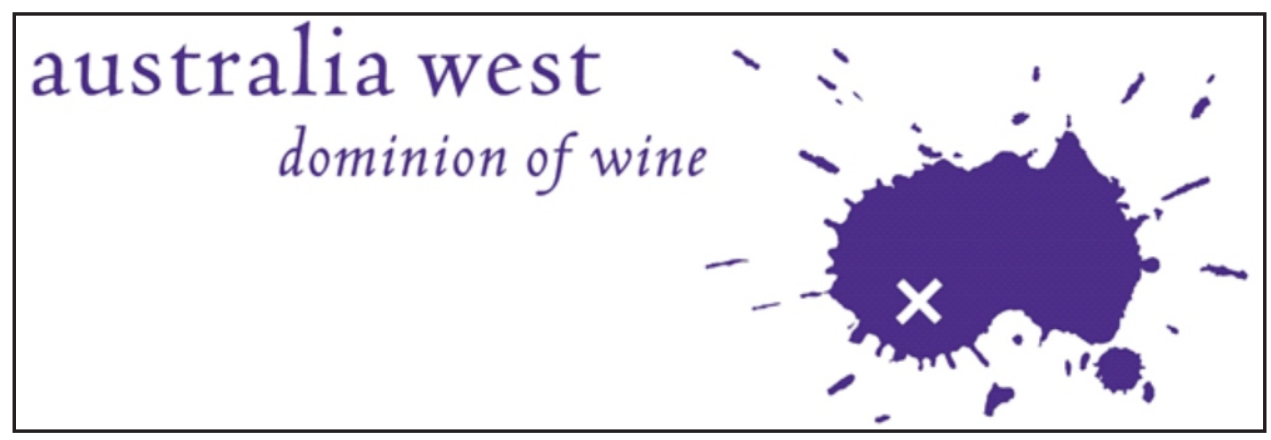

Figure 2. Wine Industry Association of Western Australia. (Used with Permission)

However the two other words - 'west' and 'dominion' - capture a history of difference, separation and colonization. The choice of 'dominion' summons a sanitized colonial heritage rather than a critical historiography. It also connotes a secondary status, a place on its way to independence but disconnected from it.

The Swan Valley was integral to the first white settlement of the Swan River Colony. The coastal strip adjacent to the newly founded Perth was dry and sandy. The arable agricultural land was in the Swan Valley. In 1829, the first year of colonial settlement, livestock was farmed in this region. The potential for viticulture was realized by the botanist Thomas Waters. He thought that the climate in the Swan Valley could produce similar wines to France or Italy. He brought root stock from South Africa and planted it at Olive Farm in South Guildford. This site is now known as Water's Edge Winery. While the early Swan Valley took on a culture of large estates, based on the British gentry, it was the Croatian farmers who arrived after the First World War that make the Sway Valley an area of vineyards rather than more traditional agricultural produce. Such an immigration history has been important to Australian wine making. The Barossa Valley would not have been successful without the German immigrants (Schmortte, 2005). Italian migrants established the vast grape-growing and wine production region of the Riverland (King and O'Connor, 2003, 24-29).

While marginal in branding terms, the Swan Valley was one of the earliest grape-growing regions in Australia. The Swan Valley is known for Verdelho and Shiraz, with a select range of regional vintage fortified wines. Besides grape growing for wine production, table grapes and dried produce, the vineyards have diversified, transforming the land into multi-use production, including olives, stone fruit and slow food staples such as chocolate and nougat, along with accommodation and tour operators. There is a range of restaurants, cafes, breweries, distilleries and a wildlife park. The goal has been to find a branding strategy that binds together a region that is close to a capital city, an airport and is a site of primary production. The phrase "Swan Valley - Perth's Valley of Taste" has been successful in creating this cultural alignment, providing a way to align a 32 kilometre strip of businesses into a "Food and Wine Trail" that includes wineries, breweries, distilleries, restaurants, cafes, accommodation and road-side stalls. There is also a strategy to incorporate art and event tourism, with the Wadjuk community offering indigenous tours through the valley (Figure 3).

The Houghton winery was founded in 1836, with the first vintage for commercial purposes released in 1859. It is the third oldest winery in Australia. Its primary 


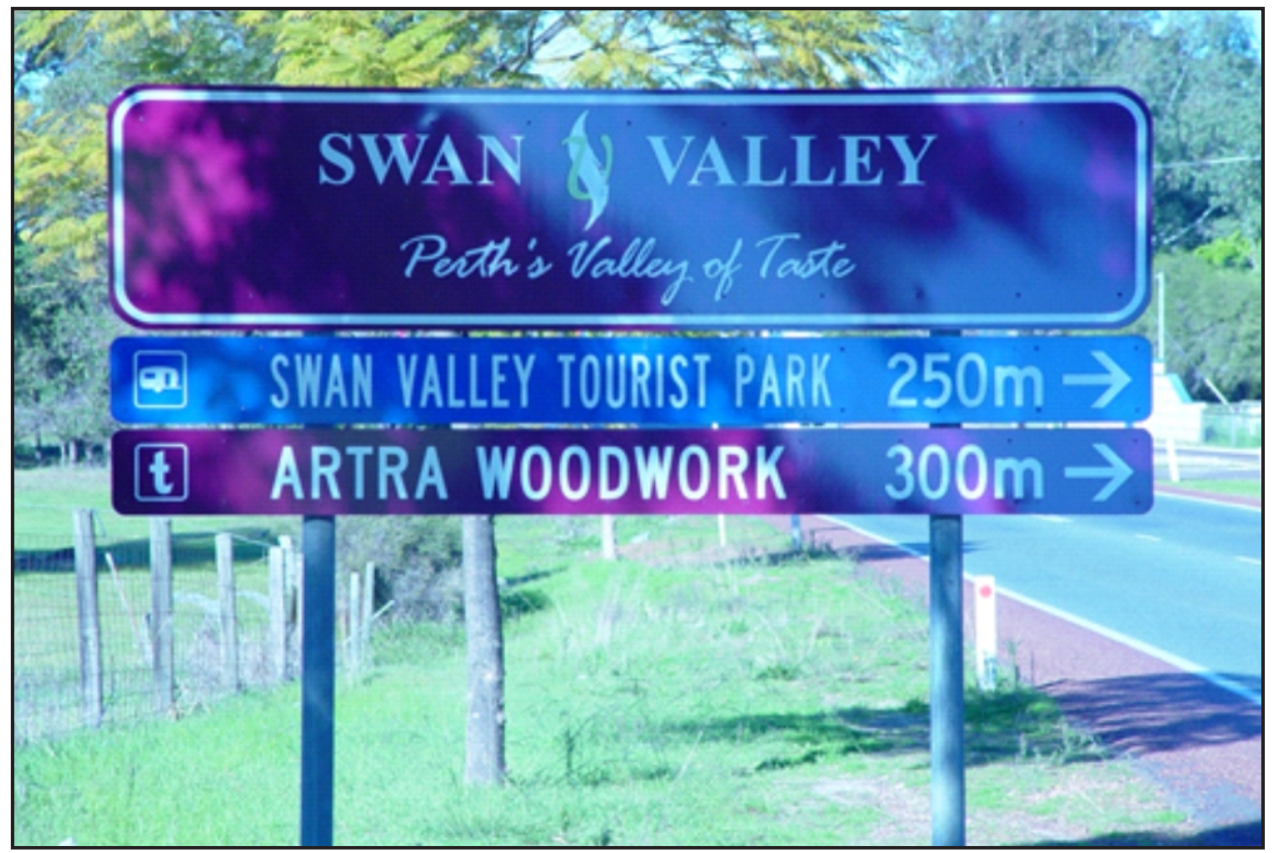

Figure 3. Perth's Valley of Taste, (Photograph by Tara Brabazon)

winemaking facilities are based in the Swan Valley, with a further winery in Nannup in the south west of Western Australia. Their "Spring in the Valley Art Collection" is part of the week-long festival that celebrates wine, food and art. Houghton's have instigated a yearly commemoration to mark this festival by unveiling a new piece of artwork given to the collection by an artist for free public display (Figure $4 \& 5$ ).

The Swan Valley creates links between food, wine and music to create both an audience and event. It is tourism in practice, rather than planning. The future of the Swan Valley is not terroir, but tourism. Appellation controls are one way to create this difference, but there are many strategies. The advantage of the Swan Valley is that it is a convenient difference, within an easy drive of a capital city. Houghton's has marketed this distinctiveness in spite of managing a serious disruption to their best known product and marketing via the appellation restrictions from the European Union.

\section{White burgundy}

Wine's a tease: it makes you want to talk about it and then a lot of what you say is nonsense ... That is one reason why some wine-talk still aims not to describe tastes and odours but metaphorically to evoke the pleasure they give. Steven Shapin $(2012,7)$

Houghton's Wines is based in the Swan Valley and is the most awarded Western Australian wine maker. They produce the highest volume of wine in Western Australia. The third oldest winery in Australia, it is now part of the Accolade Wines group. The first vines were planted in the 1830s. In 1836, three British army officers who had served together in India bought the land in the Swan Valley. While 
50 hectares are held in the Swan Valley in this historic location, the winery sources grapes throughout the state. Therefore an appellation would not be possible. The wine maker sources grapes widely and creates marketable wine based on variety, not location. Their most famous wines are chenin blanc, verdelho, chardonnay and semillon.

Houghton's had two key events in their history, and they are linked. Jack Mann is the wine maker who created a profile for the winery. Born in 1906 and dying in 1989, he created 51 vintages for Houghtons (Mulcahy, 2012). Most famously, he created White Burgundy in 1937. It was an unusual wine. It was drinkable early in its life but it also aged well. It became a different wine. But this is not a fashionable wine. Even though it was created in 1937, by the time of the EU Regulation Number 1151/2012 international trade agreements, the name had to change. The bottle had carried this designation for 70 years. The name moved from Houghton's White Burgundy through to Houghton's White Classic in 2005. The change was required because the wine did not fulfill the Protected Designation of Origin (PDO), Protected Geographical Indication (PGI) and Traditional Specialties Guaranteed (TSG). This regulation meant that not only were geographical locations protected, but also the words 'style, type or method.' "White Burgundy Method" could not be used either. Here is a photograph from the 2004 vintage, one of the last (Figure 6).

Figure 7 is a photograph of the new packaging of White Classic. T h i s w i n e matters. It is important to the history of Western Australian wine. Researchers learn about power and foodways when tracing this history. As Kevin Brabazon remembers,

I recall Sir Charles Court telling me about 10 years ago, that when he was Premier of West Australia in the 1970s, he was disappointed to learn that there were no West Australian Wines on the 'Wine List' at Parliament House Canberra. He said that he 'arranged' for a consignment of Houghtons White Burgundy to be forwarded from the Swan Valley. This wine became the first West Australian label to be on offer at Parliament House (2014).

White Burgundy was the first Western Australian wine that could mitigate the dominance of the Barossa. It was a wine that signaled the arrival of the Western Australian industry in terms of profile and branding. This wine is historically important in and of itself. Therefore, this name change was significant and detrimental to the wine, at least for a period. Some of the other range was also renamed to support this change (Figure 8).

Houghton's White Burgundy is a clear example of European history being validated and recognized as more important than Australian history. The protection of Burgundy - as a region - was reinforced through law to be more important than burgundy as a style or taste or brand.

Wine is a fetish product. Money is spent on an alcoholic refreshment that once it is drunk, loses its value. Once consumed, all that is left of the purchase is the empty bottle. Through the process of drinking, an array of experiences, histories, narratives and sensory experiences are packed into that moment. As John Varriano has realized, "wine is unique in the cultural history of food and drink" $(2010,7)$. The question is how information and knowledge about wine impacts on its purchase, consumption and re-purchase. There are opportunities for interven- 


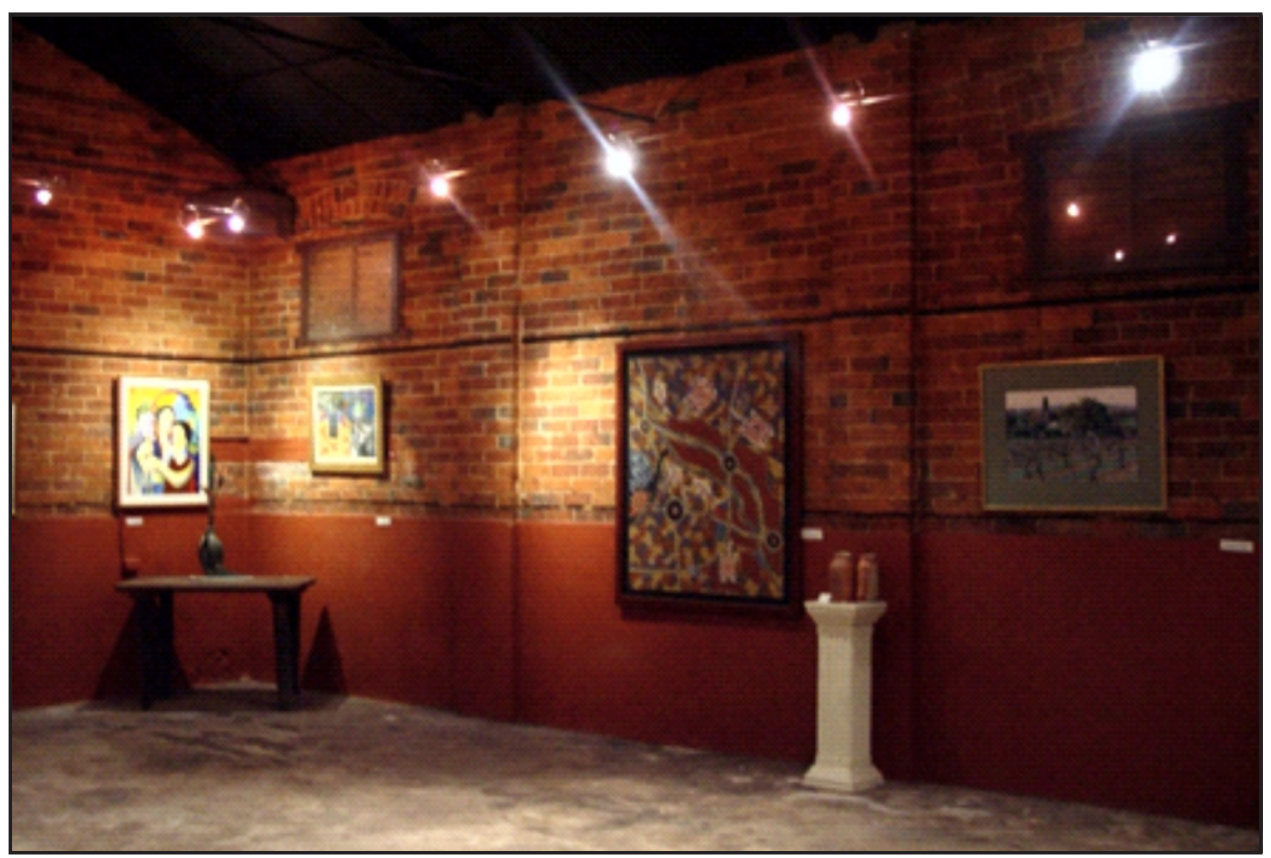

Figure 4. Houghton's Art Gallery. (Photograph by Tara Brabazon)

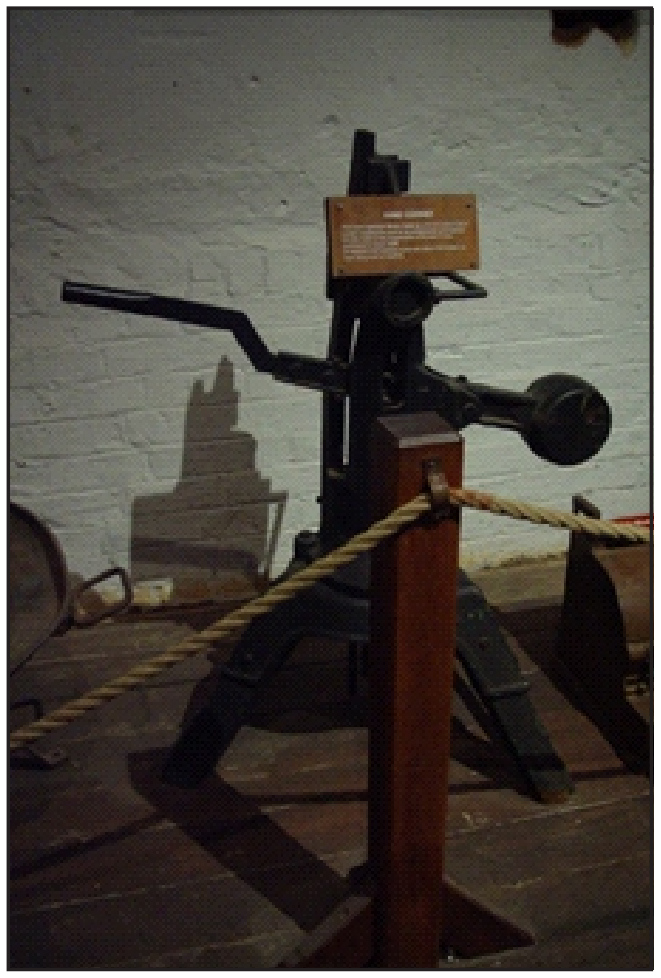

Figure 5. Houghton Museum. (Photograph by Tara Brabazon)

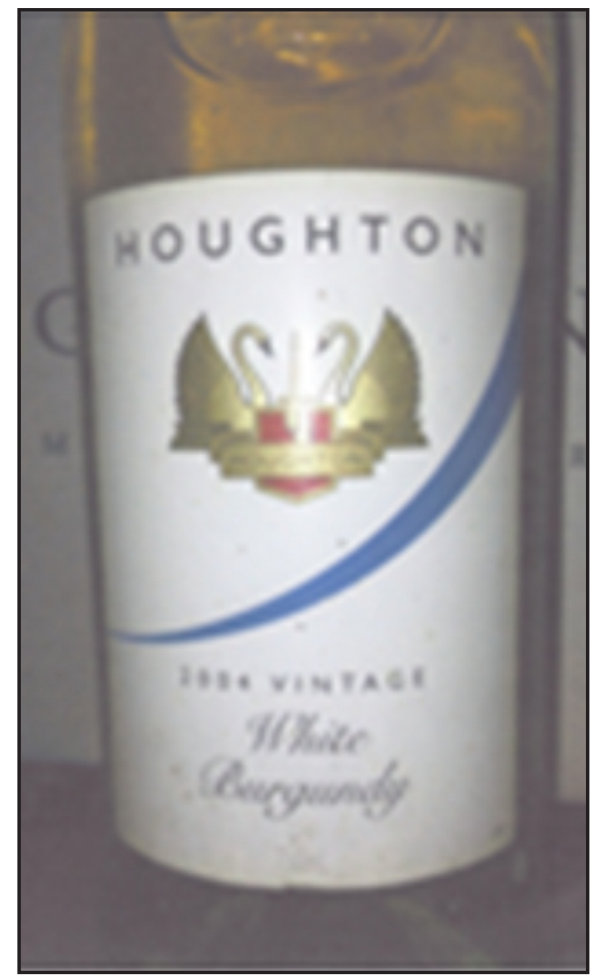

Figure 6. White Burgundy 2004 (Photograph by Stephen Brabazon) 


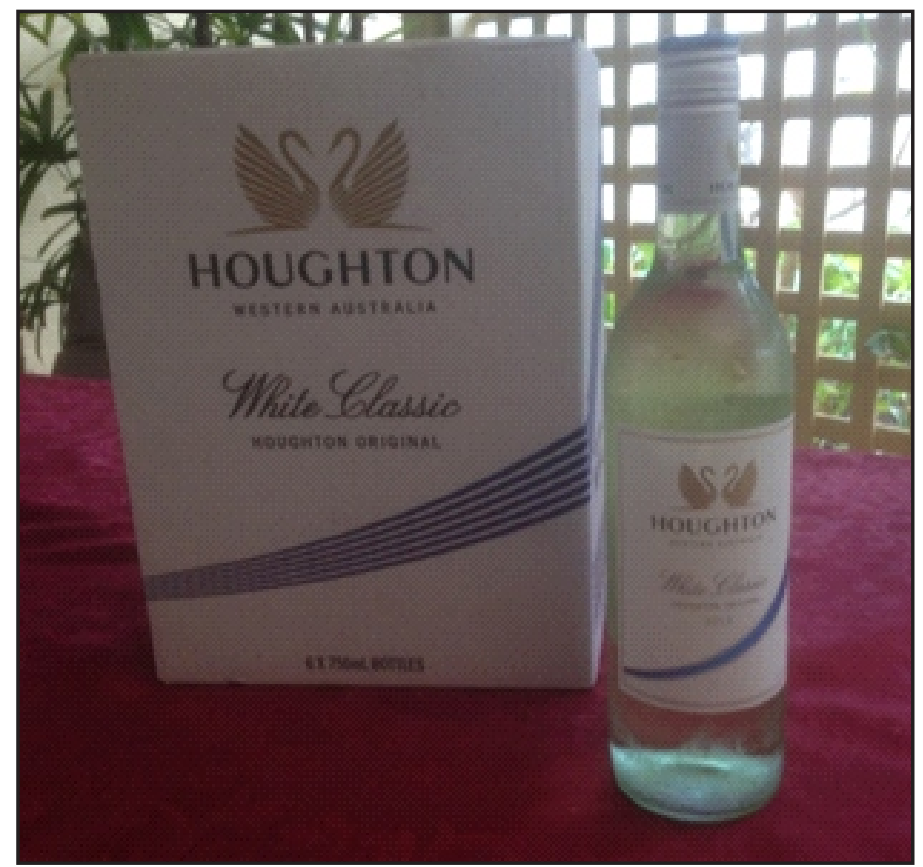

Figure 7. White Classic (Photograph by Kevin Brabazon)

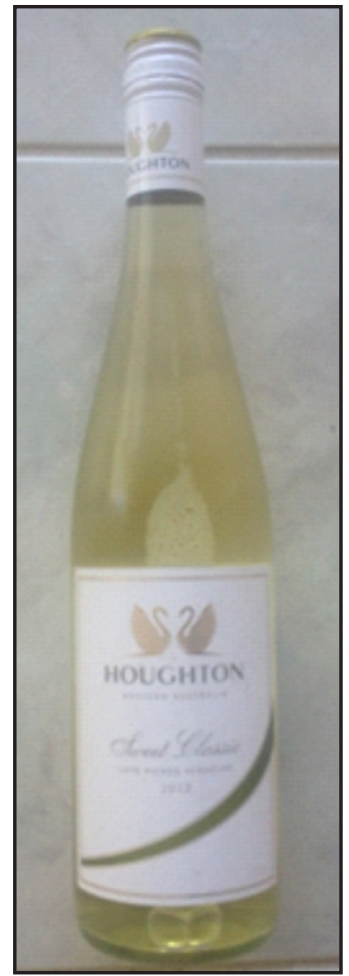

Figure 8. Sweet Classic (Photograph by Tara Brabazon)

tion in the decision-making moment between the purchase of one bottle and not another. Most consumers buy a bottle that they have purchased previously, or that has been recommended by a friend, trusted publication, waiter or an expert at a cellar door. These are analogue experiences that summon conversation, loyalty, motivation and desire. Price is a proxy for quality. So is region. Through the case (study) of Houghton's White Burgundy, the dismissal of Western Australia's wine history is in evidence, reinforcing the centrality and authenticity of Europe as international punctuation for agriculture. Houghton's White Classic has survived, but a major part of its history has not.

\section{References}

Atkin, T \& Thach, L 2012, Millennial wine consumers: risk perception and information search, Wine Economics and Policy, vol. 1, pp. 54-62

Balaam, D \& Carey, M 1981, Food Politics: the regional conflict, Croom Helm, London.

Banks, G, Kelly, S, Lewis, N \& Sharpe, S 2007, Place 'From one glance': the use of place in the marketing of New Zealand and Australian wines, Australian Geographer, vol. 38, no. 1, pp. 15-35.

Barham, E 2003, Translating terroir: the global challenge of French AOC labelling, Journal of Rural Studies, vol. 19, pp. 127-138.

Belasco, W 1989, Appetite for change; how the counterculture took on the food industry, 1966-1988, 
Pantheon, New York.

Berger, J 1990, Ways of Seeing, Penguin, London.

Boniface, P 2003, Tasting tourism: travelling for food and drink, Ashgate, Farnham.

Carolan, M 2011, Embodied Food Politics, Ashgate, Farnham.

Colman, T 2008, Wine politics: how governments, environmentalists, mobsters and critics influence the wines we drink, University of California Press, Berkeley.

Dechent, S \& Sadler, P 2010, Geographical indications in the wine industry, The Wine Industry, vol. 12, pp. 3-9.

DeLind, L 2006, Of bodies, place, and culture: re-situating local food, Journal of Agricultural and Environmental Ethics, vol. 19, pp. 121-146.

Donehower, K, Hogg, C \& Schell, E 2007, Rural literacies, Southern Illinois, University Press, Carbondale.

European Commission 1994, Agreement between Australia and the European Community on Trade in Wine, Official Journal of the European Communities, Brussels- Canberra, January 26-31, title 1 .

European Commission 2014, EU Agricultural Product Quality Policy, viewed on June 25th 2010, http://ec.europa.eu/agriculture/quality/index_en.htm.

European Union 2006, Council Regulation (EC) No 510/2006 of 20 March 2006 on the protection of geographical indications and designations of origin for agricultural products and foodstuffs, viewed on June 20th 2010,

http://europa.eu/legislation_summaries/internal_mark et/businesses/intellectual_propert y/l66044_en.htm

Exhibit EC26 1994, Australian - European Commission Ministerial Consultations, viewed on June 20th 2010,_http://trade.ec.europa.eu/doclib/docs/2004/may/tradoc_117126.pdf

Flandrin, JL \& Montanari, M 1996, Today and Tomorrow, in JL Flandrin \& M Montanari (eds), Food: A culinary history, Columbia University Press, New York.

Hall, CM, Sharples, L, Cambourne, B \& Macionis, N 2002, Wine Tourism around the world: Developments, managements and markets, Routledge, London.

Higgins, L, McGarry Wolf, M \& Wolf, M 2014, Technological change in the wine market? The role of QR codes and wine apps in consumer wine purchases, Wine Economics and Policy, vol. 3, pp. 19-27

Hira, A \& Swartz, T 2014, What makes Napa? The roots of success in the wine industry, Wine Economics and Policy, vol. 3, pp. 37-53.

Holland, T, Smith, B \& Jones, G 2014, Toward a conceptual framework of terroir tourism: a case study of the Prince Edward County, Ontario Wine Region, Tourism Planning E Development, vol. 11, no. 3, pp. 275-291.

Howes, D 2005, Empire of the Senses, Bloomsbury, London.

Jones, G, White, M, Cooper, O \& Storchmann, K 2013, Climate change and global wine quality, Climate Change, vol. 73, pp. 319-343.

King, S \& O'Connor, D 2003, Building blocks of settlement: Italians in the Riverland, South Australia, Italian Historical Society Journal, vol. 11, no. 2, pp. 24-29.

Lauden, R 2001, A plea for culinary modernism: why we should love new, fast processed food, Gastronomica, February, pp. 36-44.

Lindquist, L 1998-9, Champagne or Champagne: An examination of US failure to comply with the geographical provisions of the TRIPS agreement, Georgia Journal of International and Comparative Law, vol. 27, pp. 309-344.

Lyons, K 2006, Environmental values and food choices: views from Australian organic food consumers, Journal of Australian Studies, vol. 87, pp. 155-166.

Marx, K 2011, Economic and Philosophic Manuscripts of 1844, Martino Publishing, Eastford.

Mason, L 1999, Traditional Foods of Britain: an inventory, Prospect Books, Totnes. 
Miller, J \& Deutsch, J 2009, Food Studies: an introduction to research methods, Berg, New York.

Moran, W 2001, Terroir - the human factory, Australian \& New Zealand Wine Industry Journal, vol. 16, pp. 32-51.

Mulcahy, C 2012, Jack Mann, Australian Dictionary of Biography, vol. 18, viewed on July 20th 2010, http://adb.anu.edu.au/biography/mann-jack-14906

Nutzenadel, A \& Trentmann, F (eds) 2008, Food and Globalization: Consumption, Markets and Politics in the Modern World, New York, Berg.

Overton, J \& Heitger, J 2008, Maps, markets and Merlot: the making of an antipodean wine appellation, Journal of Rural Studies, vol. 24, pp. 440-449.

Overton, J 2010, Consumption of space: land, capital and place in the New Zealand wine industry, Geoforum, vol. 41, pp. 752-762.

Pigott, S 2006, The truth in Thai wine, Gastronomica, vol. 6, no. 2, pp. 76-78.

Ray, C 1998, Culture, intellectual property and territorial rural development, Sociologia Ruralis, vol. 38, pp. 3-20.

Reid, J, Green, B, Cooper, M, Hastings, W, Lock, G \& White, S 2010, Regenerating rural social space? Teacher education for rural-regional sustainability, Australian Journal of Education, vol. 54, no. 3, pp. 262-276.

Rovamo, O 2006, Monopolising Names? Faculty of Law, Helsinki University, viewed on June 20th 2010, http://ethesis.helsinki.fi/julkaisut/oik/julki/pg/rovamo/monopoli.pdf.

Saunders, P 2004, Wine Label Language, Firefly, Auckland.

Schmortte, J 2005, Attitudes towards German immigration in South Australia in the postsecond world war period, 1947-60, The Australian Journal of Politics and History, vol. 51, pp. $530-545$.

Shapin, S 2012, Plonk and plonkers, The Guardian, vol. May 5, pp. 7.

TRIPS, Article 22 (1), viewed on June 20th 2010, http://www.lclark.edu/live/files/3842.

TRIPS, Article 23 (1), viewed on June 20th 2010, http://www.lclark.edu/live/files/3841.

Vadour, E 2002, The quality of grapes and wine in relation to geography: notions of terroir at various scales, Journal of Wine Research, vol. 13, pp. 117-141.

Varriano, J 2010, Wine: A cultural history, Reaktion. London.

Warwick, E \& Overton, J 2011, Defining regions: the making of places in the New Zealand wine industry, Australian Geographer, vol. 42, no. 4, pp. 419-433.

Wilson, T 2004, Globalization, differentiation and drinking cultures, an anthropological perspective, Anthropology of Food, vol. 3, pp. 4-11.

Wilson, T 2005, Drinking cultures: Alcohol and identity, Berg, Oxford and New York.

World Intellectual Property Organization 2014, About Geographical Indicators, viewed on June $20^{\text {th }}$ 2010, http://www.wipo.int/geo_indications/en/about.html.

Xu, Y, Castel, T, Richard, Y, Cuccia, C \& Bois, B 2012, Burgundy regional climate change and its potential impact on grapevines, Climate Dynamics, vol. 39, pp. 1613-1626. 